Original scientific paper

\title{
PERCEPTIONS OF CZECH RURAL LIFE BY ITS INHABITANTS IN CONNECTION TO TOURISM
}

\section{PERCEPCE ŽIVOTA NA ČESKÉM VENKOVĚ JEHO OBYVATELI VE VZTAHU K CESTOVNÍMU RUCHU}

\author{
Renata KLUFOVÁa ${ }^{\mathrm{a}}$, Marek ŠULISTA ${ }^{\mathrm{a}}$ \\ a University of South Bohemia, Faculty of Economics, klufova@ef.jcu.cz, sulista@ef.jcu.cz
}

Cite this article: Klufová, R., Šulista, M. (2018). Perceptions of Czech Rural Life by its Inhabitants in Connection to Tourism. Deturope, 10(1), 5-32

\begin{abstract}
Rural tourism in the EU Member States is an important segment of the tourist market. Rural areas achieve multiple benefits from developing rural tourism. From this point of view, rural tourism revitalises rural areas, decreases depopulation, enables the valorisation of economic resources, etc. On the other hand, rural tourism highlights, and thus preserves, the cultural, environmental, natural, traditional, and historical characteristics of a specific rural area. In this way, the regional diversity, authenticity, and recognisability are maintained in the united Europe, which provides a competitive advantage to the European Union's tourist market. However, bottom-up initiatives within the local communities and appropriate attitudes towards the development of tourism are important. The aim of this contribution is to evaluate the perceptions of Czech rural life by its population with a focus on tourism. The evaluation is a part of a broad-based questionnaire survey aimed at the assessment of different aspects of rural life. The perceptions of tourism are monitored in conjunction with other characteristics of self-assessment by respondents and their assessment of the villages in which they live. Classical dependencies of the obtained data from the survey were analysed at first, and then multidimensional statistical methods (CATegorical Principal Component Analysis, cluster analysis) were used in the hypothesis testing of the interference of "hard" and "soft" factors of the rural development. This comparison confirms that "hard" and "soft" development factors really affect each other. Therefore, rural development strategies need to be designed so that both sets of factors are in line with the aim of synergy. The hard localization and realization factors themselves, without supporting the development of soft factors, do not have the desired effect.
\end{abstract}

Keywords: rural tourism, inhabitants' perceptions, questionnaire survey, Categorical Component Analysis, cluster analysis

\begin{abstract}
Abstrakt
Venkovský turismus představuje ve státech EU významnou součást nabídky cestovního ruchu. Venkovské oblasti získávají z rozvoje cestovního ruchu četné benefity. V tomto slova smyslu se rurální turismus podílí na revitalizaci venkovských oblastí, snižování populačních ztrát, valorizaci ekonomických zdrojů atd. Vedle toho také vychází a vede k zachování kulturního prostředí, prírodních, historických a kulturních charakteristik konkrétní oblasti. Tímto způsobem je podporována ve sjednocené Evropě regionální diverzita a autenticita, což poskytuje konkurenční výhodu na trhu $\mathrm{CR}$ v rámci EU. Důležitá je však iniciativa a vhodné postoje $\mathrm{k} C \mathrm{CR}$ zdola, v rámci místních komunit. Cílem příspěvku je hodnocení postojů obyvatel českého venkova $\mathrm{k}$ jejich životu na venkově se zaměřením na cestovní ruch. Hodnocení je součástí široce pojatého dotazníkového šetření, jehož cílem bylo hodnotit různé aspekty života na venkově. Vnímání cestovního ruchu je sledováno ve spojení s ostatními charakteristikami sebehodnocení respondentů a jejich hodnocení obcí, ve kterých žijí. V datech z dotazníkového šetření byly analyzovány klasické závislosti, při testování hypotéz o prolínání „tvrdých“ a „měkkých“ faktorů rozvoje venkova
\end{abstract}


byly využity vícerozměrné statistické metody (kategoriální analýza hlavních komponent, shluková analýza). Provedené srovnání potvrzuje, že se „tvrdé“ a „měkké“ faktory rozvoje skutečně navzájem ovlivňují. Rozvojové strategie venkovského prostoru je tedy třeba navrhovat tak, aby byly obě skupiny faktorů v souladu, s cílem vzájemné synergie. Samotné tvrdé lokalizační a realizační faktory bez podpory rozvoje měkkých faktorů nemají žádoucí účinek.

Klíčová slova: venkovský CR, percepce obyvatel, dotazníkové šetření, Kategoriální analýza hlavních komponent, shluková analýza

\section{INTRODUCTION}

At present, rural agriculture is not a dominant economic activity. An increasing proportion of the population commutes to work outside their home village. The significance of tourism is gaining importance, and also the specific Czech phenomenon, which is second housing, maintains its important role. The development and quality of life in municipalities, cities, regions and states is closely linked to people-to-people relationships, mutual trust or trust in institutions; all the elements that are collectively referred to as social capital. Social capital is a dynamic structure that regulates individual behaviour in networks and vice versa (Giddens, 1984). In terms of the potential or the realization of certain goals, it may also be perceived as a collective resource (Havlíček, 2007; Pisseli, 1999). Although we know of a number of examples of inconsistent use of social capital (e.g. Granovetter, 1973, draws attention to the exclusivity of networks whose actors abuse them for short-term personal gain), we consider it, like Putnam (1993, 2001), primarily as a positive value and a development factor.

\section{Rural transformation and rural tourism}

The political and economic transformation commenced after 1989 has significantly influenced all the social reality of the country, including the countryside. The changes in the last decades, consisting of a decline in agricultural activity and light industry, have resulted in population decline and economic stagnation, and are linked to serious social problems. Significant changes in the socio-economic environment have led to an increasing rural differentiation. These changes have had the greatest impact on small rural municipalities, which attempted to suspend the overall decline by replacing the fall of traditional forms of livelihood with the service sector (Horáková and Fialová, 2012, p. 17). A gradual transition from agriculture to the development of services is referred to as the post-productivist transition (Ilbery, 1998). Modern post-industrial rurality has emerged, providing new opportunities for the rural use of new alternative forms of livelihoods for the rural population. One of these forms is the use of rural space through sustainable forms of tourism. 
Currently, rural tourism is one of the fastest growing forms of tourism (Roberts and Hall, 2001). Petr (2012) discusses the difficulties in viewing of the basic terms and hence the difficulties regarding measurability of the rural tourism phenomenon. Bramwell (1994) considers whether the physical existence of tourism activities in rural areas forms an individual "rural tourism" sector. According to Stříbrná (2005), problems arise in connection with the intermingling of urban and rural tourism in suburban areas, where are the differences between rural and urban areas are decreasing due to globalization, suburbanization, ICT development or even the "non-rural" character of some tourism activities operating in rural areas. Similar findings are suggested by the results of the survey presented in this paper. The difficulties associated with the definition of rural tourism lead to problems of measurability of its impacts at the local, regional and international levels, reflecting the diversity of definitions not only of the rural, but also of rural tourism in different countries (Hall et al., 2003).

According to the Dictionary of Tourism (Zelenka and Pásková, 2012, p. 601), rural tourism is an aggregated label for a type of tourism connected with multi-day visits and recreational activities in the countryside (walking, cycling or horseback riding, observation and care of domestic animals, consumption of home-made food, etc.), and with accommodation in private or smaller collective establishments. The attractiveness of rural tourism is based on some aspects of a real or fabulous view of the rural way of life (vast, quiet, peaceful landscape, unpolluted air, work activities, customs and folklore, etc.). Sharpley and Roberts (2004, p. 119) describe rural tourism as a "dynamic phenomenon". One of the most influential approaches to defining rural tourism is the OECD definition created in collaboration with Bernard Lane (Lane, 1994, 2009). This definition describes rural tourism as a discrete activity with typical characteristics (scale, location and character).

\section{Tourism as a factor of rural development}

The countryside was traditionally a place of production, dominated by farming, but changes in farming practices, mechanisation and the influences of globalisation have profoundly affected the fabric of rural communities, which have increasingly shifted from being production spaces to consumption spaces in which tourism plays an important role (Marsden, 1998; McAreavey and McDonagh, 2010). Rural restructuring, as a result of these changes in agriculture, has had significant effects on the social and cultural make-up of rural communities. Out-migration, especially of young people, has been a common practice as people seek work in urban areas to replace now lost, land-based occupations (Butler et al., 1998). Some rural regions in western countries have seen an influx of new wealthy residents from urban and semi-urban areas who 
seek leisure and relaxation in the countryside as a form of rural gentrification (Sutherland, 2012). These changes have affected the cohesion and vitality of many rural communities.

In the Czech Republic (Petr, 2012), the question of the countryside was long in the shadow of more important problems whose solutions were given priority (the transformation of the economy and political system, restructuring, unemployment, etc.). Due to the structural reforms, many Czech rural municipalities have experienced a significant drop in production both in agriculture and in light industry. The transformation of Czech agriculture has led to changes in all the levels of social environment of the countryside (Horáková and Fialová, 2012). Changes in ownership, transformation of agricultural cooperatives and the privatization of state farms led to a decline and restructuring of agricultural production. The number of the economically active population in agricultural production has radically decreased, which has led to significant economic and social problems and the consequent outflow of young people into cities. This significantly changed the age structure of the rural population.

Extensive changes in socio-economic conditions have led to increasing rural differentiation. Municipalities in urban hinterlands have seen the inflow of the middle and upper strata of urban residents into new residential locations, leading to a general revitalization of these municipalities. However, the above-mentioned changes had the biggest impact on small, remote rural villages that are not located in a convenient location near a city. Most notably, the changes affected the so-called problematic recreational countryside, which includes a large part of the borderland settled after World War II by new inhabitants, which combines both tourist attractive areas with a high proportion of second housing and major socio-economic problems (Perlín et al., 2010; Horáková and Fialová, 2012). In an effort to slow down the economic downturn, population outflow and overall decline, municipalities have been considering alternative development opportunities in the context of rural diversification. The aim was, among other things, to achieve the multi-functionality of rural space. One of the alternatives is the development of various forms of sustainable tourism in rural areas.

The post-productivist countryside is characterised by multi-functionality. While still spaces of (often limited) production through drastically changed agricultural practices, many rural areas are now also 'places to play' for the relatively wealthy, often urban, citizens (Sutherland, 2012). Rural regions have seen increases in the number of tourists visiting, in the variety of recreational activities on offer for tourists, and in the nature of those activities, shifting from passive enjoyment of rural environments to also include more active, 
technological and resource-intensive activities such as adventure sports (Butler et al., 1998; Roberts and Hall, 2004). These changes in the characteristics of rural tourism require rural communities to provide high levels of service and often specialist skills and support. Such expertise is not always available within rural communities without significant investment in training and education, which is often not forthcoming, especially in poor rural communities. This limits the ability of these communities to get involved in and benefit from rural tourism opportunities. Tourism has been seen as a key mechanism for revitalising rural communities and has been supported by local and national governments across the world, including in western countries such as Portugal and France (Costa and Chalip, 2005), through to the former Soviet nations of Eastern Europe (Dimitrovski et al., 2012) and in many developing countries throughout sub-Saharan Africa, Asia and South America (Briedenhann and Wickens, 2004), with varying degrees of success. There are examples of cases where rural tourism development has directly benefited local communities economically and socially, such as through helping to preserve regional identity and local traditions and keeping young people in rural regions (Gulcan, et al., 2009; Dimitrovski et al., 2012). However, rural tourism development has often been limited by poor planning, lack of infrastructure and inward investment, and corruption (Macbeth et al., 2004).

While tourism development can bring positive social and economic benefits to rural communities, careful planning, community involvement and transparency are essential at all stages. Hall et al. (2004) argue that tourism works best in areas with a thriving and diverse rural economy in which tourism is just one amongst many regeneration strategies. Without this, tourism development can intensify inequality and other problems (turistification).

It is also important to mention the issue of promoting tourism in rural areas. From the experience in Austria the key elements of 'new rural tourism' in harmony with man, culture and nature and based upon future market trends are: accommodation which is original and typical for the area; a restaurant sector going for local atmosphere and both seasonal and local specialities; new profiles focusing on specific themes (e.g. health, culture) or groups (e.g. families, the active elderly); a natural and cultural environment which is refined and presented in an appealing and didactic manner, taking the interests of the resident population into account and establishing a new partnership with agriculture (Hummelbrunner and Miglbauer, 1994).

One of the main tools of rural area promotion is financial support from the EU (Jarábková et. al., 2016) as a tool for rural diversification. Other tools include information, actions of non-governmental organizations, various forms of activation of local communities, 
networking (Roberts and Hall, 2001; March and Wilkinson, 2009) etc. Cawley and Gillmor (2008) even developed a model of integrated tourism, which took account of the various resources (cultural, social, environmental, economic), their use, and the role of pertinent stakeholders. The tourism industry, especially rural tourism, is largely dominated by small and medium sized enterprises (SMEs) and is often considered less innovative than other industries. Cosma et al. (2014) describe the role of innovativeness in the rural tourism promotion on the example of Romanian rural tourism.

\section{Perception of rural tourism in the literature}

Tourism development renders various economic, socio-cultural and environmental changes on the host community's life, some more beneficial than others (Lee, 2013). Thus, the participation and support of local residents is imperative for the sustainability of the tourism industry at any destination (Gursoy et al., 2010). Understanding the residents' perspective can facilitate policies which minimize the potential negative impacts of tourism development and maximize its benefits, leading to community development and greater support for tourism. A rich body of literature investigates the relationships between residents' perceived impacts of tourism and their support for tourism development (e.g., Gursoy et al., 2010; Ko and Stewart, 2002; Nunkoo and Ramkissoon, 2012). Yet, most of these studies adopt an a priori categorization of potential impacts (into positive or negative economic, social-cultural and environmental impacts or simply costs and benefits), whereas limited attention is given to the residents' own evaluation of the extent to which they perceive an impact as being positive or negative (Andereck, Valentine, Knopf and Vogt, 2005).

Citizen or civic involvement refers to the residents' general involvement in local community groups and activities, meaning their involvement in the civic community (Allen et. al, 1988; Ko and Stewart, 2002). The degree of involvement has demonstrated an influence on residents' overall attitudes towards tourism development (Allen et al., 1988; Ko and Stewart, 2002). Allen et al. (1988) argue that a negative attitude towards tourism development is influenced by people's opportunity for civic involvement. Thus, if local residents are locally involved in both tourism and non-tourism related issues, they are inclined to have a more positive attitude towards tourism development in general.

Local residents are key stakeholders in the process of achieving sustainable development in tourism (Eligh, Welford and Ytterhus, 2002). A main focus in tourism impact research has been to study their perceptions of tourism impacts, measuring these perceptions in relation to 
how the impacts affect either their community, their quality of life (QOL), and/or their support for future tourism development (Andereck and Nyaupane, 2011; Ap and Crompton, 1998; Easterling, 2005; Ko and Stewart, 2002). The underlying assumption is that tourism development has consequences for local residents' well-being (Kim, Uysal and Sirgy, 2013), and the support of those residents is vital for the tourism industry, as it makes up a major part of the tourist experience (Ap, 1992).

From a sustainable development perspective (i.e. economic, sociocultural, environmental impacts), the evaluative component also highlights which impact dimensions are more or less important to residents. In addition to theoretical relevance, by the application of an importance measure, the inclusion of an evaluative component would facilitate tourism planning efforts. More precise information about local residents' attitudes would help legitimize the planning process (Jamal and Getz, 1995) and facilitate the adoption of a community-based approach to sustainable development, where benefits and costs to the host population are the starting point in the tourism planning process (Saarinen, 2006).

It is important to note that local residents are a heterogeneous group of people (Ap and Crompton, 1998; Easterling, 2005; Lankford and Howard, 1994; Wall and Mathieson, 2006). The application of stakeholder theory (Easterling, 2005), social exchange theory (Andereck, Valentine, Knopf and Vogt, 2005; Ap, 1992) and segmentation analysis (Fredline and Faulkner, 2000) have mainly illustrated this heterogeneity.

Czech literature describing the attitudes of the population to the development of tourism is also relatively rich and diverse, whether it is the final reports of various research, strategic documents, monographs (Horáková and Fialová, 2012), journal articles or final papers. Some examples are noted below. The relationship of the local population to the development of tourism in specially protected areas as in the example of the Podyji National Park is described by Lindner and Pachrová (2012). Questionnaire surveys of residents, visitors and key actors are among the methods used by the LAC (Limits to Acceptable Change) model, which is used for the planning and regulation of biosphere impacts (see, for example, Pásková, 2003). The attitudes of tourists to the protected areas are studied for example by Navrátil et al. (2013) or Navrátil et al. (2014). The attitudes of tourists and entrepreneurs in relation to the influence of wind farm construction on the territorial development of tourism in Slezská Harta are analysed by Frantál and Kunc (2008). The characteristics of the area image perceived by its inhabitants in relation to tourism are described by Chalupová et al. (2017), Chromý et al. (2014), Patočka and Heřmanová (2008). 


\section{OBJECTIVES AND METHODS}

The aim of the paper is to evaluate the perception of the Czech countryside by its inhabitants, both in relation to tourism and in a wider development context. For this purpose, the perceptions of the rural population of themselves and the perception of the village in which they live correspond to the main parts of the questionnaire described below. The information obtained from the questionnaire survey ("soft" data) is further compared to the previously published typology of rural municipalities (Klufová, 2016) based on the quantitative data from Census 2011 ("hard" data). The aim was to verify whether "hard" and "soft" rural development factors intersect and how. When analysing the data, the authors proceeded from the following hypotheses:

Hypothesis 1: There is a statistically significant dependence between the self-assessment of the respondents and the individual types of the above mentioned rural typology, i.e. the selfperception of individual respondents (including the relation to visitors and holidaymakers) differs in different types of rural areas.

Hypothesis 2: There is a statistically significant dependence among respondents' assessment of their village and individual types of the rural typology mentioned above, i.e. the perceptions of the municipality by individual respondents (including attitudes to tourism support) differ in different types of rural areas.

Hypothesis 3: In the rural area of the Czech Republic (on the basis of the self-assessment of respondents), several different types of inhabitants of the Czech countryside (profiles of the inhabitants) can be identified. The share of them will also vary according to the types of the rural typology.

Hypothesis 4: In the rural areas of the Czech Republic (based on the perception of the municipalities), their inhabitants can identify several basic development factors that will vary according to the types of the rural typology.

\section{Czech rural typology}

The typology of rural municipalities, created by Klufová (2016) in the analysis of the demographic development of the Czech countryside, is based on quantitative data from the Census 2011. Six types of rural communities have been identified (Fig. 1). 
Figure 1 Czech rural typology

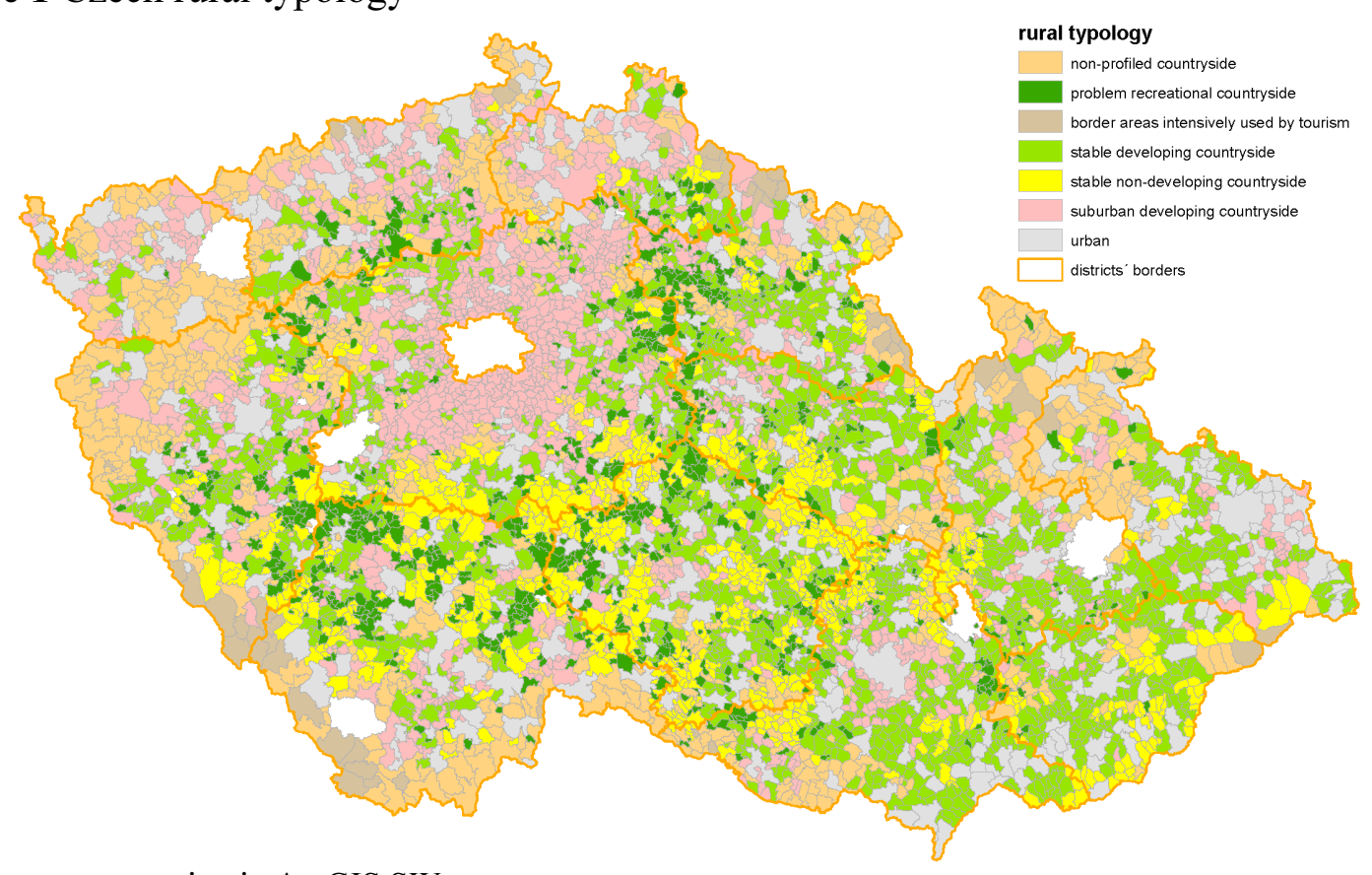

Source: own processing in ArcGIS SW

\section{Statistical methods}

Due to the fact that the questionnaire survey mainly obtained categorical (ordinal) data, it had to be processed by adequate statistical methods. The basic test used to determine the interdependence of two categorical variables is the chi-square test of independence. If the assumption for chi-square test in the contingency table is not fulfilled then so-called exact tests are used, e.g. Fisher's exact test (see e.g. Řezanková, 2010). Where the assumptions for the chi-square test were not met, alternative methods (exact tests, or calculation of the significance level reached by Monte Carlo method - see e.g. Pecáková, 2014) were applied in testing Hypotheses 1 and 2.

The basic data reduction methods are Principal Component Analysis (PCA) and Factor Analysis (FA). These methods allow us to replace a plurality of the original variables with a smaller number of latent variables, with the original variables assuming mutual linear relationships. Because the PCA method is designed to analyse quantitative continuous variables, other methods are needed for categorical variables. One of these is CATPCA (CATegorical Principal Component Analysis).

When using the CATPCA method, the use of optimal scaling allows scaling variables at different levels. Categorical variables are optimally quantified within the specified dimensionality. It is also possible to model non-linear relations between variables. The scales of the individual variables may differ. This method also does not require compliance with the assumption of multidimensional normality of data (Šulc and Řezanková, 2015). The choice of the measurement scale of a given variable is very important as it affects the structure of the 
correlation matrix. The choice of the appropriate scale is made by the authors. The details of the choice are described, for example, by Linting (2007), and the complete use of the method by Meulman and Heiser (1993).

The CATPCA method was used separately to reduce dimensionality within the selfestimation of respondents and separately for the assessment of the municipality by respondents, followed by cluster analysis in testing Hypotheses 3 and 4.

\section{Questionnaire survey in the Czech municipalities}

In order to identify the perceptions of the development of rural communities by their inhabitants, a large questionnaire survey was carried out in 2010 and 2011, where 1000 respondents over 18 years old were addressed (see Fig. 2) within a defined set of 100 rural municipalities (10 respondents were interviewed in each of them). The questionnaire was conducted by Focus agency in autumn of 2010 and in spring of 2011. The municipalities of "border countryside intensively used by tourism" are not included in the analysis due to their specificity and small frequency.

The main part of the questionnaire was composed of several parts: the characteristics of the respondent (using the Lickert scale 1 to 5 evaluated by the respondents), the characteristics of the municipality, the willingness of the respondent to help the municipality, the life in the community (clubs, societies etc.), the activity of the council and involvement of the respondent in its activities, economic activity and the household characteristics of the respondent. In the paper, we focus only on the self-assessment of respondents and the evaluation of the municipality in relation to tourism.

Figure 2 Sample of rural municipalities in questionnaire survey

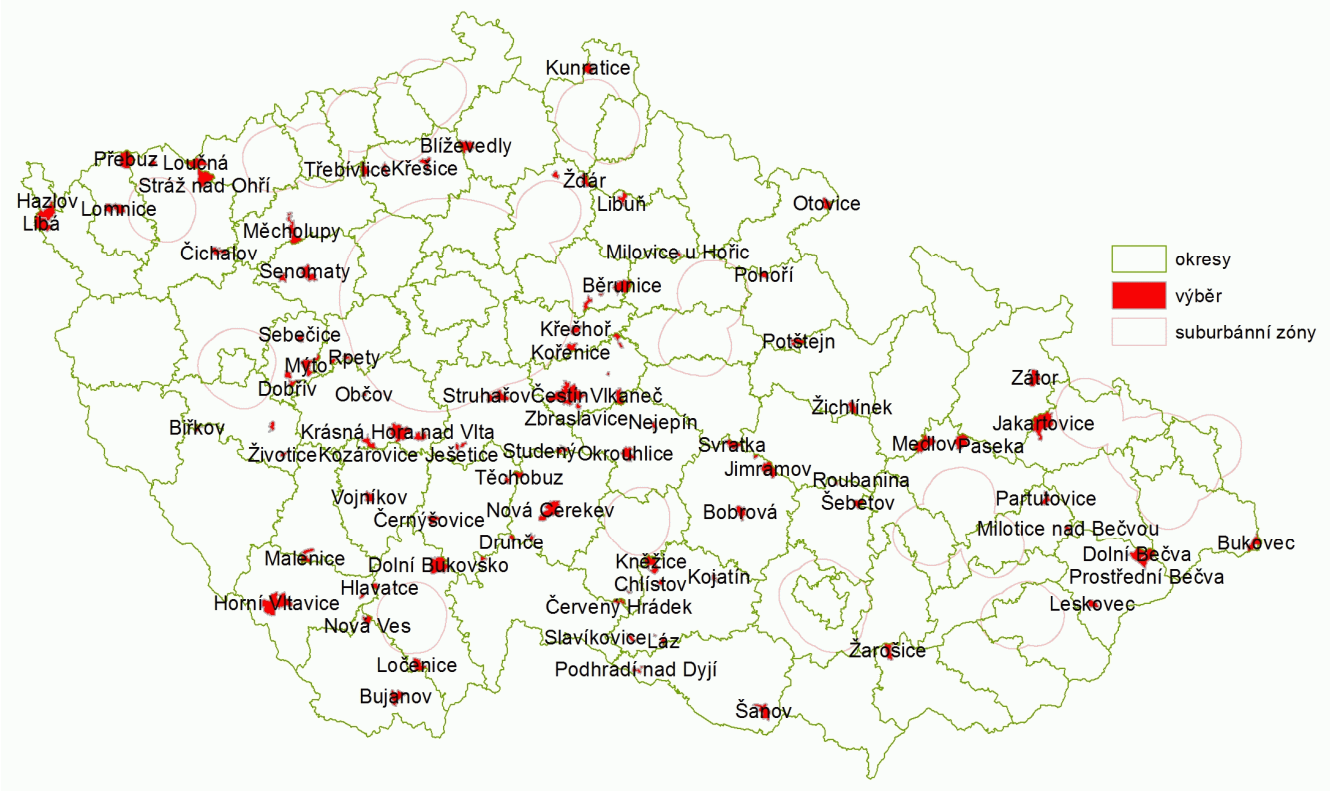

Source: own processing in ArcGIS SW 


\section{RESULTS AND DISCUSSION}

\section{Self-evaluation of the Czech rural inhabitants}

The respondents had a range of characteristics and their task was to identify those activities or attributes that characterize the particular respondent, their convictions, attitudes and behaviour. The respondents responded to 15 statements (see Tab. 1) to assign a value from 1 to 5, according to the degree of matching the offered characteristic to the respondent's character ( 1 means the highest degree of agreement and 5 means the absolute disapproval). The respondents could tick all or none of the responses according to the degree of their agreement to the particular characteristics.

When looking at respondents' attitudes towards visitors in relation to other characteristics of themselves, regardless of their membership in the individual types of the Czech rural typology, we find (as expected) that those who positively perceive the visitors to the village and thus support the development of tourism in the municipality, rated themselves as active people.

In the context of contingency tables analysis, the dependency of respondents' perceptions on the type of rural community in which they live was first tested. Tab. 2 shows a statistically significant dependence of the attitude towards the visitors of the municipality on the type of the municipality, i.e. the attitudes of respondents from different types of rural typology to tourism and also other characteristics of self-evaluation differ.

Table 1 Correlation between positive attitude of respondents to visitors/holidaymakers and other characteristics of respondents' self-evaluation

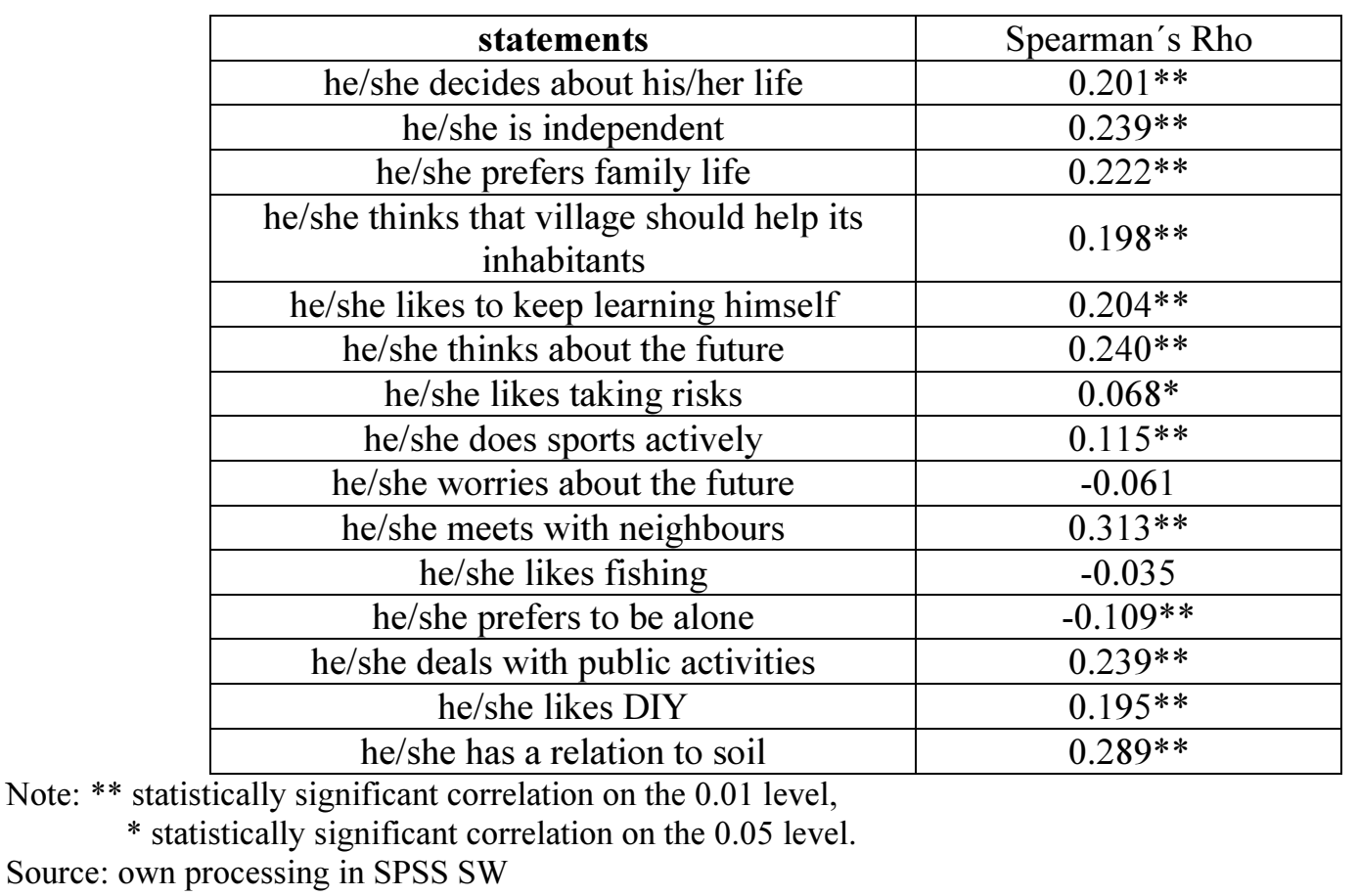


Tab. 3 shows a generally positive attitude of respondents to visitors in all types of rural municipalities (more than $60 \%$ of the population of the problematic recreational and stable developing countryside has expressed a lower or higher degree of agreement; in the case of the non-profiled and stable developing countryside, this share reaches $60 \%$, a higher degree of disagreement (compared to other types) was recorded only in the suburban countryside and the stable non-developing rural areas. In this case (comparing with other results), we can agree with Allen et al. (1988), who argue that a negative attitude towards tourism development is influenced by people's opportunity for civic involvement.

The suburban countryside consists of municipalities that have experienced significant changes in the character of the construction, but also in the way of life in these municipalities, which is much closer to the town. Residential functions predominate here, they can partly fulfil recreational functions in suburban tourism, for instance in form of guesthouses (Navrátil et al., 2012). This may also lead to a moderately neutral attitude of their inhabitants towards the development of tourism as it does not play an important role in the development of this group of municipalities (e.g. Stříbrná, 2005).

Table 2 Contingency Table Analysis

\begin{tabular}{|l|r|r|r|r|}
\hline \multicolumn{1}{|c|}{ statements } & & df & $\boldsymbol{p}$-value & $\begin{array}{c}\text { Monte Carlo } \\
\text { p-value (conf. int.) }\end{array}$ \\
\hline he/she decides about his/her life & 16.923 & 16 & & $0.384(0.371 ; 0.396)$ \\
\hline he/she is independent & 19.302 & 16 & & $0.247(0.236 ; 0.258)$ \\
\hline he/she prefers family life & 32.168 & 16 & & $\mathbf{0 . 0 0 8}(0.006 ; 0.010)$ \\
\hline $\begin{array}{l}\text { he/she thinks that village should help its } \\
\text { inhabitants }\end{array}$ & 22.697 & 16 & & $0.109(0.101 ; 0.151)$ \\
\hline he/she likes to keep learning himself & 28.197 & 16 & $\mathbf{0 . 0 3 0}$ & \\
\hline he/she thinks about the future & 15.197 & 16 & & $0.507(0.4995 ; 0.520)$ \\
\hline he/she likes taking risks & 29.932 & 16 & $\mathbf{0 . 0 1 8}$ & \\
\hline he/she does sports actively & 48.175 & 16 & $\mathbf{0 . 0 0 0}$ & \\
\hline he/she worries about the future & 17.150 & 16 & 0.376 & \\
\hline he/she meets with neighbours & 19.893 & 16 & 0.225 & \\
\hline he/she likes fishing & 40.394 & 16 & $\mathbf{0 . 0 0 1}$ & \\
\hline he/she prefers to be alone & 55.111 & 16 & $\mathbf{0 . 0 0 0}$ & \\
\hline he/she deals with public activities & 73.351 & 16 & $\mathbf{0 . 0 0 0}$ & \\
\hline he/she likes DIY & 64.390 & 16 & $\mathbf{0 . 0 0 0}$ & \\
\hline he/she has a relation to soil & 58.477 & 16 & $\mathbf{0 . 0 0 0}$ & \\
\hline $\begin{array}{l}\text { he/she positively perceives } \\
\text { holidaymakers/visitors }\end{array}$ & 38.048 & 16 & $\mathbf{0 . 0 0 1}$ & \\
\hline
\end{tabular}

Source: own processing in SPSS SW

The remaining types of municipalities differ in their attitudes towards visitors statistically significantly, but they are associated with a predominant positive relationship with visitors. There is probably no municipality with intensive use of mass forms of tourism in the sample which would affect the living and social environment of the site. Thus, the respondents of 
these groups of municipalities have no negative experience with the intensive use of their territory by tourism, touristification and other negative phenomena resulting from excessive tourism intensity. Recreational use prevails in the form of second housing and "soft" forms of rural tourism (agro-tourism, tourism, etc.).

Table 3 Respondents' attitudes to visitors/holidaymakers according to the Czech rural typology (\% in particular type of municipalities)

\begin{tabular}{|l|c|c|c|c|c|}
\hline type & $\begin{array}{c}\text { strongly } \\
\text { agree }\end{array}$ & agree & $\begin{array}{c}\text { neither agree } \\
\text { nor disagree }\end{array}$ & disagree & $\begin{array}{c}\text { strongly } \\
\text { disagree }\end{array}$ \\
\hline non-profiled countryside & 26.5 & 32.3 & 28.6 & 7.4 & 5.2 \\
\hline problematic recreational countryside & 30.9 & 33.0 & 24.3 & 7.0 & 4.8 \\
\hline stable developing countryside & 20.4 & 41.1 & 29.6 & 6.3 & 2.6 \\
\hline stable non-developing countryside & 27.3 & 32.0 & 24.7 & 11.3 & 4.7 \\
\hline suburban countryside & 13.8 & 34.4 & 29.4 & 12.5 & 9.9 \\
\hline
\end{tabular}

Source: own processing in SPSS SW

Figure 3 Respondents' attitudes towards visitors/holidaymakers according to rural typology

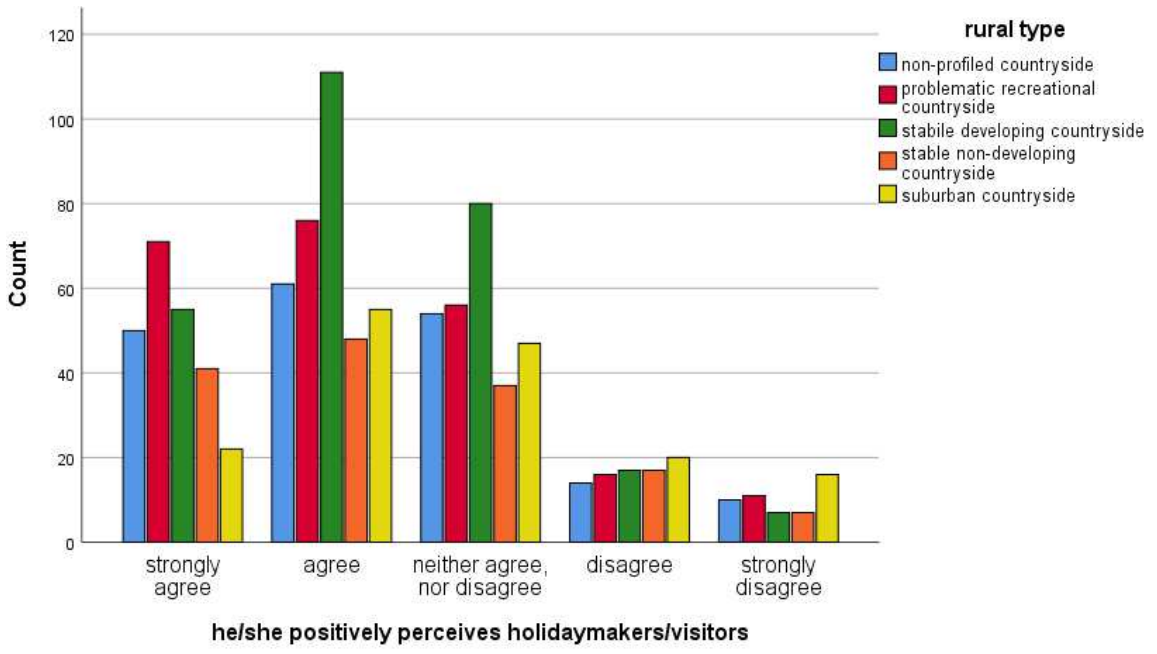

Source: own processing in SPSS SW

Recreational houses can be found in almost every rural village, with a higher concentration in mountainous and sub-mountainous areas (Vystoupil et al., 2006) and in areas defined as internal peripheries (Musil and Müller, 2008). Owners of these properties usually seek peace, which is in a certain sense contrary to mass tourism. They usually have positive neighbourly ties with local residents. In addition, the owners of second houses have in many cases preserved the preservation of a number of rural settlements, notably in uninhabited areas due to the expulsion of German population after the World War II and in the population losing areas where the outflow of young people was first caused by socialist industrialization and later administrative measures forming the settlement system (Perlín et. al., 2010; Horáková and Fialová, 2012). 


\section{Assessment of the municipality by its respondents}

Looking at the evaluation of tourism support by the municipalities, irrespective of their affiliation to individual types of rural typology (Tab. 4), we can find a positive correlation of tourism support with localization factors (nice nature, healthy air, healthy environment, forest existence, realization factors, available services, sports opportunities, good connections with the city, better water than in the city, available medical care, the possibility to buy daily goods, the possibility of free time) as well as selective factors (it is safe, who wants to do business will surely find the opportunity, good neighbourly relations, the opportunity to find a job ...).

Table 4 Correlation between tourism support by municipality and its other characteristics

\begin{tabular}{|l|c|}
\hline \multicolumn{1}{|c|}{ statements } & Spearman's Rho \\
\hline It is safe here. & 0.015 \\
\hline You can use the public library and the web. & $0.226^{* *}$ \\
\hline People understand each other. & $0.142^{* *}$ \\
\hline There are opportunities to do sports. & $0.378^{* *}$ \\
\hline Traditions are supported. & $0.246^{* *}$ \\
\hline $\begin{array}{l}\text { There are good conditions for young people to start } \\
\text { their lives. }\end{array}$ & $0.272^{* *}$ \\
\hline $\begin{array}{l}\text { Those who want to do business find an opportunity } \\
\text { here. }\end{array}$ & $0.320^{* *}$ \\
\hline There is affordable housing here. & $0.133^{* *}$ \\
\hline Services are available here. & $0.277^{* *}$ \\
\hline It is close to attractive nature. & $0.111^{* *}$ \\
\hline There is a good connection with the city. & $0.233^{* *}$ \\
\hline There is better water than in the city. & $0.187^{* *}$ \\
\hline There is healthy air. & $0.195^{* *}$ \\
\hline Medical care is available here. & $0.289^{* *}$ \\
\hline There is a healthy environment. & $0.260^{* *}$ \\
\hline There are good relations among neighbours. & $0,130^{* *}$ \\
\hline It is possible to build family houses here. & 0.061 \\
\hline There is the possibility to buy good for daily use. & $0.252^{* *}$ \\
\hline There are forests in the neighbourhood & $0.071^{*}$ \\
\hline I can find a job. & $0.300^{* *}$ \\
\hline There is enough space for self-realization. & $0.292^{* *}$ \\
\hline
\end{tabular}

Note: ** statistically significant correlation on the 0.01 level,

* statistically significant correlation on the 0.05 level.

Source: own processing in SPSS SW

The municipalities' rating by respondents according to rural typology (Tab. 5) shows statistically significant differences of individual types of municipalities for almost all characteristics, except for the opinion on the correspondence in the inhabitants' communication (people understand themselves) and good relations among neighbours.

Respondents' opinions on whether the municipality supports tourism in its territory are more different in comparison with their personal attitudes within individual groups of 
municipalities. Residents of municipalities with problematic recreational countryside (more than $40 \%$ of respondents in this group expressed a certain degree of disagreement) and suburban countryside $(36.9 \%)$ believe that tourism is not supported in their communities. The largest support for tourism by the municipality is declared by the inhabitants of stable developing countryside (60.7\%) and non-profiled countryside (59.3\%).

Table 5 Contingency Table Analysis

\begin{tabular}{|l|r|r|r|r|}
\hline \multicolumn{1}{|c|}{ statements } & $\chi^{2}$ & df & $\boldsymbol{p}$-value & $\begin{array}{c}\text { Monte Carlo } \\
\text {-value (conf. int. })\end{array}$ \\
\hline It is safe here. & & & & $\mathbf{0 . 0 2 3}(0.019 ; 0.027)$ \\
\hline You can use the public library and the web. & 133.038 & 20 & $\mathbf{0 . 0 0 0}$ & \\
\hline People understand each other. & & & & $0.226(0.215 ; 0.236)$ \\
\hline There are opportunities to do sports. & 190.082 & 20 & $\mathbf{0 . 0 0 0}$ & \\
\hline Traditions are supported. & 142.573 & 20 & $\mathbf{0 . 0 0 0}$ & \\
\hline $\begin{array}{l}\text { There are good conditions for young people to } \\
\text { start their lives. }\end{array}$ & 129.189 & 20 & $\mathbf{0 . 0 0 0}$ & \\
\hline $\begin{array}{l}\text { Those who want to do business find an } \\
\text { opportunity here. }\end{array}$ & 115.251 & 20 & $\mathbf{0 . 0 0 0}$ & \\
\hline There is affordable housing here. & 76.451 & 20 & $\mathbf{0 . 0 0 0}$ & \\
\hline Services are available here. & 204.683 & 20 & $\mathbf{0 . 0 0 0}$ & \\
\hline It is close to attractive nature. & & & & $\mathbf{0 . 0 0 9}(0.007 ; 0.110)$ \\
\hline There is a good connection with the city. & 236.539 & 20 & $\mathbf{0 . 0 0 0}$ & \\
\hline There is better water than in the city. & & & & $\mathbf{0 . 0 1 3}(0.010 ; 0.015)$ \\
\hline There is healthy air. & & & & $\mathbf{0 . 0 0 4}(0.002 ; 0.006)$ \\
\hline Tourism is supported. & 119.009 & 20 & $\mathbf{0 . 0 0 0}$ & \\
\hline Medical care is available here. & 161.850 & 20 & $\mathbf{0 . 0 0 0}$ & \\
\hline There is a healthy environment. & & & & $\mathbf{0 . 0 0 7}(0.005 ; 0.009)$ \\
\hline There are good relations among neighbours. & & & & $0.071(0.064 ; 0.077)$ \\
\hline It is possible to build family houses here. & 113.051 & 20 & $\mathbf{0 . 0 0 0}$ & \\
\hline There is the possibility to buy good for daily use. & 348.485 & 20 & $\mathbf{0 . 0 0 0}$ & \\
\hline There are forests in the neighbourhood & & & & \\
\hline I can find a job. & 169.374 & 20 & $\mathbf{0 . 0 0 0}$ & $\mathbf{0 . 0 0 0}$ \\
\hline There is enough space for self-realization. & 82.972 & 20 & $\mathbf{0 . 0 0 0}$ & \\
\hline Soure: ow por & & \\
\hline
\end{tabular}

Source: own processing in SPSS SW

Table 6 Respondents' attitudes to tourism support according to rural typology ( $\%$ in the type of municipalities)

\begin{tabular}{|l|c|c|c|c|c|}
\hline type & $\begin{array}{c}\text { strongly } \\
\text { agree }\end{array}$ & agree & $\begin{array}{c}\text { neither agree, } \\
\text { nor disagree }\end{array}$ & disagree & $\begin{array}{c}\text { strongly } \\
\text { disagree }\end{array}$ \\
\hline non profiled countryside & 34.4 & 24.9 & 20.1 & 9.5 & 11.1 \\
\hline $\begin{array}{l}\text { Problematic recreational } \\
\text { countryside }\end{array}$ & 15.2 & 16.1 & 27.8 & 20.9 & 20.0 \\
\hline $\begin{array}{l}\text { Stable developing } \\
\text { countryside }\end{array}$ & 29.6 & 31.1 & 28.5 & 8.9 & 1.9 \\
\hline $\begin{array}{l}\text { Stable non-developing } \\
\text { countryside }\end{array}$ & 25.3 & 17.3 & 30.7 & 22.0 & 4.7 \\
\hline Suburban countryside & 15.0 & 22.5 & 25.6 & 20.6 & 16.3 \\
\hline
\end{tabular}

Source: own processing in SPSS SW 
The municipalities of problematic recreational countryside represent small municipalities by population and also by their size with a very high ageing index and the associated higher value of the economic burden index. Compared with other types, they also report a high proportion of commuters to places outside the village and a high proportion of those employed in the primary sector. In this group, almost $70 \%$ of family houses are used for recreation. With regard to the population size of these municipalities, and their unsatisfactory human and social capital and small municipal budgets, it is probably very problematic to support tourism development and tourism prevails here in the form of second houses.

The municipalities of this group also showed a high chronological average of net migration over the period 2001-2012, which could indicate, for example, the change in the use of some second houses from recreation towards permanent housing or, for example, some manifestations of amenity migration (Bartoš et. al., 2011; Sutherland, 2012). This corresponds to a change in the population development in the municipalities of this group, which in the period 1991-2001 decreased by an average of $8 \%$, while in the decade 2001-2011 increased by $3 \%$. In this group, however, the lowest building activity was recorded both in the period 1991-2001 and in 2001-2011. It also shows the lowest share of persons employed in selected service sectors (accommodation and catering), the lowest number of collective accommodation establishments, the lowest share of households with Internet access and the worst disposal of basic services and technical infrastructure from all rural types, which can limit further tourism development (Macbeth et al. 2004). For this reason, it is marked as problematic recreational countryside. These types of municipalities occur almost exclusively in the Czech part.

Suburban communities, as mentioned above, have seen significant changes in the character of their building construction, but in particular in their way of life, which is much closer to the urban one. Residential functions predominate in them, and in part they can fulfill a recreational function in suburban tourism. This is also to some extent the predominant views of their inhabitants on "unsupported" tourism.

The stable developing countryside consists of larger municipalities by population, characterized by high population density, building density and relatively favorable age structure. These municipalities are located predominantly in the Moravian part of the state, then in the Vysočina and Pardubice regions. These are municipalities with the highest share of employees per employed persons and average employer share, the lowest share of those employed in the primary sectors, but also the highest share of commuters to places outside 
their village. Municipalities of this type have typically above-average shares of natives, believers, and married people, indicating social stability.

Figure 4 Respondents' attitudes to tourism support according to rural typology

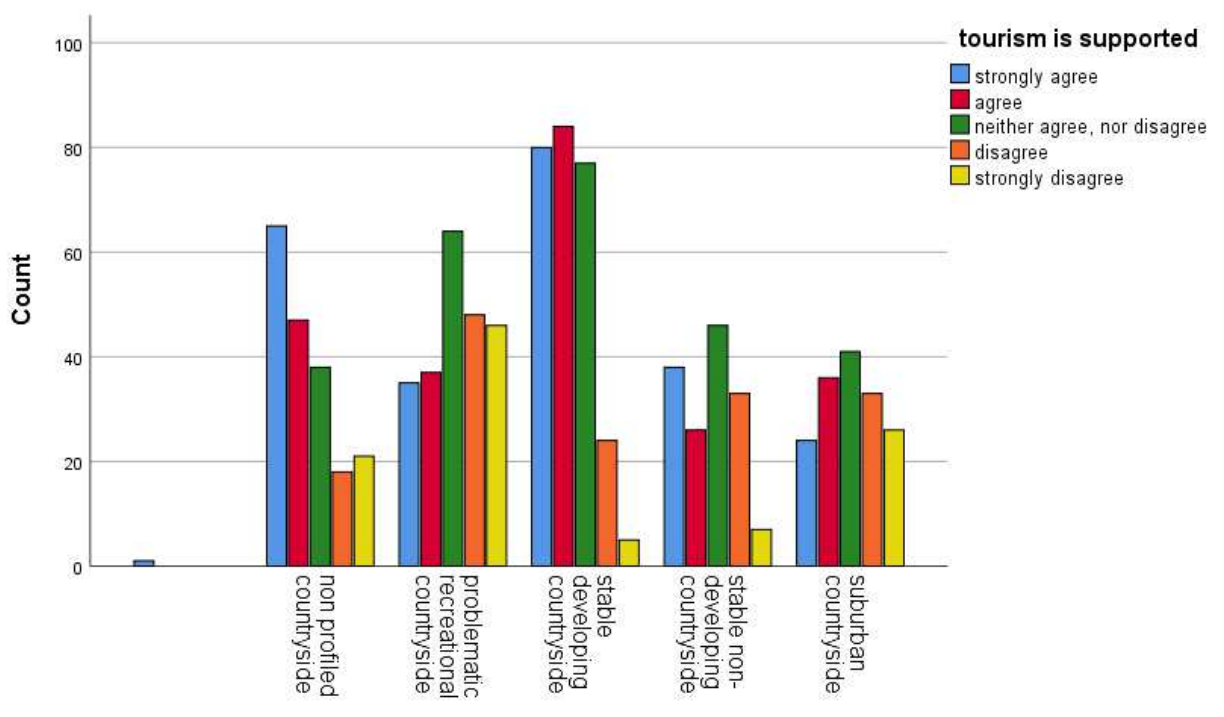

Source: own processing in SPSS SW

This group of municipalities also recorded intensive construction in 1991-2011, as well as population growth (an average of 7\%) and migration gains. The group shows the lowest share of unoccupied houses and homes used for recreation. In terms of the proportion of households connected to the Internet, service facilities and basic technical infrastructure, this group can be described as above-average. Nevertheless, respondents of this type of municipality declare almost two-thirds of the support for the development of tourism by the municipalities, which can correspond to reality (due to their facilities and stability), as tourism is generally considered as one of the mechanisms of economic development of rural municipalities. It corresponds to the idea of the best tourism development conditions in areas with diversified economy (Hall et al., 2004).

The non-profiled countryside consists of smaller populations, but by area larger villages with worse accessibility which are located mainly in the border areas of South Bohemia, West Bohemia and the Jeseníky regions. Compared to other types, the municipalities in this group are characterized by a relatively favorable age structure, low education, low share of believing population, the lowest share of married people and a lower share of natives - low social stability and quality of human capital. These municipalities are made up mostly of more local parts. The structure of employed people is dominated by employees. The share of employers (who are potential creators of new jobs) in the total number of employees is the lowest in this group. The proportion of family houses is also lower. Compared with other groups, no 
significant building activity was recorded either in the 1991-2001 period or in 2001-2011. Regarding the population, this group of municipalities stagnated between 1991 and 2001, with an average population growth of 5\% in 2001-2011 due to migration gains. These are areas where there has been an intense population change in the past, which has negatively affected both social stability and human capital. The availability of basic services and technical infrastructure can be considered below average in this group. The increase in the population over the last decade, together with the favorable share of recreational areas and the intensive use of these areas by mass forms of tourism, as well as a relatively favorable age structure, indicate the potential for further development (with appropriately chosen regional development tools). However, the low level of education and the low share of employers are a certain handicap.

\section{Profile of rural inhabitants}

Seeking for answers to the question of how the typical rural inhabitants look and whether the inhabitants with different self-perceptions live in different types of rural municipalities (Hypothesis 3), CATPCA and cluster analysis were used. Is it possible to identify different types of rural population on the basis of their self-assessment and the evaluation of the community they live in? And how far does the rural typology (made from "hard" data) coincide with the profile of the rural inhabitant (obtained by the analysis of "soft" data)?

Using the Multidimensional Scaling approach allows scaling variables at different levels. Categorical variables are optimally quantified within the specified dimensionality. It is also possible to model non-linear relations between variables.

In the case of self-assessment of respondents, CATPCA led to a reduction of the dimension in the data when the original 16 ordinal variables (the last question was excluded for low frequencies) received 5 main components, which account for $59.5 \%$ of the total variability of the set. Component loadings of individual variables are contained in Tab. 7. Individual components - dimensions - can be perceived as certain types or characters of personality that can be described roughly as follows: 1 - active family type; 2 - active sportsman; 3 - engaged DIY guy, 4 - independent, decisive; 5 - pessimist, loner.

Tab. 7 shows a positive relationship to holidaymakers and visitors in an active family type, while the pessimist, and loner, has a rather ambivalent relationship.

The values of the component scores of self-evaluation of individual respondents then served as input variables for cluster analysis to reveal typical groups of Czech rural inhabitants. Using the K-means method, respondents were divided into 6 clusters. The number 
of clusters was estimated by the Ward method. The fact that all five components are statistically significant in the distribution of respondents to clusters is shown in Tab. 8 .

Table 7 Component loadings

\begin{tabular}{|l|c|c|c|c|c|}
\hline \multirow{2}{*}{ statements } & \multicolumn{5}{c|}{ components } \\
\cline { 2 - 6 } & 1 & 2 & 3 & 4 & 5 \\
\hline he/she decides about his/her life & $\mathbf{0 . 5 8 3}$ & 0.105 & -0.269 & $\mathbf{0 . 5 7 1}$ & 0.085 \\
\hline he/she is independent & $\mathbf{0 . 6 1 7}$ & 0.113 & -0.190 & $\mathbf{0 . 5 5 9}$ & 0.095 \\
\hline he/she prefers family life & $\mathbf{0 . 6 4 0}$ & -0.259 & -0.172 & -0.094 & 0.141 \\
\hline $\begin{array}{l}\text { he/she thinks that a village should help its } \\
\text { inhabitants }\end{array}$ & $\mathbf{0 . 5 4 1}$ & -0.277 & -0.274 & -0.035 & 0.026 \\
\hline he/she likes to keep learning himself & 0.348 & $\mathbf{0 . 6 0 1}$ & -0.167 & -0.303 & 0.238 \\
\hline he/she thinks of the future & $\mathbf{0 . 5 5 1}$ & 0.227 & -0.352 & -0.231 & 0.311 \\
\hline he/she likes to take risks & $\mathbf{- 0 . 0 4 4}$ & $\mathbf{0 . 7 5 7}$ & 0.044 & 0.010 & -0.027 \\
\hline he/she actively does sports & 0.075 & $\mathbf{0 . 7 9 2}$ & -0.103 & -0.118 & -0.049 \\
\hline he/she is worried by the future & 0.211 & -0.327 & 0.129 & -0.347 & $\mathbf{0 . 4 9 6}$ \\
\hline he/she meets with neighbours & $\mathbf{0 . 5 6 5}$ & -0.200 & 0.143 & -0.050 & $\mathbf{- 0 . 4 5 1}$ \\
\hline he/she likes fishing & 0.031 & 0.373 & $\mathbf{0 . 5 0 6}$ & 0.201 & -0.073 \\
\hline he/she likes to be alone & -0.112 & 0.013 & $\mathbf{0 . 5 5 0}$ & 0.309 & $\mathbf{0 . 4 3 4}$ \\
\hline he/she deals with public activities & 0.408 & 0.355 & $\mathbf{0 . 5 0 7}$ & -0.156 & -0.037 \\
\hline he/she likes DIY & 0.479 & -0.049 & $\mathbf{0 . 6 0 2}$ & -0.028 & 0.055 \\
\hline he/she has a relation to the soil & $\mathbf{0 . 5 9 4}$ & -0.270 & $\mathbf{0 . 4 2 9}$ & -0.092 & -0.027 \\
\hline $\begin{array}{l}\text { he/she positively perceives } \\
\text { holidaymakers/visitors }\end{array}$ & $\mathbf{0 . 5 7 9}$ & 0.060 & -0.031 & -0.165 & $\mathbf{- 0 . 4 4 7}$ \\
\hline
\end{tabular}

Source: own processing in SPSS SW

Table 8 Clustering of component scores - Analysis of Variance

\begin{tabular}{|l|c|c|c|c|c|c|}
\hline \multirow{2}{*}{ components } & \multicolumn{2}{|c|}{ cluster } & \multicolumn{2}{c|}{ error } & \multicolumn{2}{c|}{} \\
\cline { 2 - 7 } & Mean square & df & Mean square & df & F & $p$-value \\
\hline 1 (active family type) & 86.541 & 5 & 0.570 & 993 & 151.851 & 0.000 \\
\hline 2 (active sportsman) & 103.781 & 5 & 0.483 & 993 & 214.655 & 0.000 \\
\hline 3 (engaged DIYer) & 88.966 & 5 & 0.558 & 993 & 159.414 & 0.000 \\
\hline $\begin{array}{l}\text { 4 (independent, } \\
\text { decisive) }\end{array}$ & 77.690 & 5 & 0.615 & 993 & 126.356 & 0.000 \\
\hline 5 (pessimist, loaner) & 85.144 & 5 & 0.577 & 993 & 147.481 & 0.000 \\
\hline
\end{tabular}

Source: own processing in SPSS SW

Rural residents are usually not sharply defined types (Ap and Crompton, 1998; Easterling, 2005; Lankford and Howard, 1994; Wall and Mathieson, 2006). Detailed analysis of the individual clusters and their mutual comparison showed that all clusters significantly differ statistically in all dimensions. In cluster 1 , there is a population dominated by "independent, determined" residents, not doing traditional work at home and reluctant to take risk, i.e. 
people who are actively employed and no longer have enough time for hobbies. To a certain extent, this corresponds to a weaker link to family and family values.

Cluster 2 consists of exclusively "traditional" people - with relationships to family, community, land and other values, and ready to take risks. We could label these people as "traditional active country people". The relationship with family values and willingness to take risks is the strongest in this cluster. Cluster 3 forms, compared to the previous cluster, people who are rather "staid", reluctant to take risks, pro-family, devoted to domestic work and DIY, i.e. relying mainly on themselves. We could label this type of rural population as "traditional passive villagers".

Table 9 Shares of individual types of inhabitants in municipalities according to rural typology $(\%)$

\begin{tabular}{|l|c|c|c|c|c|c|}
\hline \multirow{2}{*}{ municipality type } & \multicolumn{7}{|c|}{ clusters (inhabitants) } \\
\cline { 2 - 7 } & 1 & 2 & 3 & 4 & 5 & 6 \\
\hline stable developing & 22.2 & 9.6 & 20.4 & 11.9 & 13.3 & 22.6 \\
countryside & $(37.3)$ & $(18.3)$ & $(29.7)$ & $(22.2)$ & $(23.1)$ & $(28.9)$ \\
\hline stable non-developing & 12.0 & 15.3 & 22.7 & 14.7 & 17.3 & 18.0 \\
countryside & $(11.2)$ & $(16.2)$ & $(18.4)$ & $(15.3)$ & $(16.7)$ & $(12.8)$ \\
\hline problematic & 14.8 & 15.2 & 12.2 & 11.7 & 14.8 & 31.3 \\
recreational & $(21.1)$ & $(24.6)$ & $(15.1)$ & $(18.8)$ & $(21.8)$ & $(34.1)$ \\
countryside & & & & & & \\
\hline non-profiled & 11.1 & 17.5 & 18.5 & 17.5 & 22.8 & 12.7 \\
countryside & $(13.0)$ & $(23.2)$ & $(18.9)$ & $(22.9)$ & $(27.6)$ & $(11.4)$ \\
\hline suburban countryside & 17.5 & 15.6 & 20.6 & 18.8 & 10.6 & 16.9 \\
& $(17.4)$ & $(17.6)$ & $(17.8)$ & $(20.8)$ & $(10.9)$ & $(12.8)$ \\
\hline
\end{tabular}

Note: The first value represents the frequency within a given type of municipality, the value in brackets, the frequency within a given cluster.

Source: own processing in SPSS SW

Persons who can be termed "extroverts" (non-family, social, to some extent intolerant, but engaged, ready to take risks) prevail in Cluster 4. This type of rural inhabitant is characterized by a high degree of individualism. People dominating Cluster 5 can be described as "introverts" (pessimistic, solitary DIYers, little interest in family and traditional values). The last cluster can be characterized as "passive or resigned". The distribution of individual types of rural inhabitants in individual types of municipalities according to the above mentioned rural typology is presented in Tab. 9.

Through the clusters, there predominate the characteristics of rural areas as a space where people are more tied to the place where they were born, indicating a keeping of traditions and different ways of life into which they have been born. It is passed down from generation to generation and is difficult to teach. It is a guarantee of continuity of traditions. Those types of 
municipalities, in which certain problems are manifested, also face a lower quality of human and social capital, i.e. with a higher proportion of persons belonging to Clusters 3 and 5 .

The high percentage of people who like to decide on their lives can be perceived as being traditionally used in the country to rely on their abilities and decision-making about themselves, their own homes and their economies. In the clusters of progressive people, with the younger average age of the population, there is not only self-confidence and decisionmaking, but also sporting activities which are stronger than in clusters where the older population is. Lower sports activity can be explained because people in the country have enough natural movement at work, and by work around the house and in gardens. Therefore, so they do not have to actively do sport like people in the city.

\section{Respondents' perception of their municipality}

In searching for answers to the question as to how rural people perceive their village and the extent to which their perception is consistent with rural typology (Hypothesis 4), CATPCA and cluster analysis were again used. Can the different types of rural communities be identified based on their perception by local residents? And how far does the rural typology (made from "hard" data) coincide with the typology of the countryside (obtained from the analysis of "soft" data)?

In the case of municipalities' assessments by their inhabitants, CATPCA led to the reduction of the dimension in the data when the original 22 ordinal variables (the last question was excluded for low frequencies) resulted in 3 main components explaining $47.9 \%$ of the total variability of the set. For better interpretation of the components, the varimax rotation method was used in this case. Component loads of individual variables are contained in Tab. 10. Individual components - dimensions - can be seen as certain characteristics of municipalities important for their inhabitants, which can be described roughly as follows: 1 socio-economic conditions; 2 - natural environment; 3 - social capital.

The variable "tourism is supported" is mostly correlated to the component of the socioeconomic condition, which is quite logical since appropriate socio-economic conditions (realization factors) are required for a development of tourism services and an overall support of tourism in a given location. It is also positively correlated to the natural environment (locational factors). 
Table 10 Component loadings

\begin{tabular}{|l|l|l|l|}
\hline \multirow{2}{*}{ statements } & \multicolumn{3}{c|}{ components } \\
\cline { 2 - 4 } & \multicolumn{1}{|c|}{1} & \multicolumn{1}{c|}{2} & \multicolumn{1}{c|}{3} \\
\hline It is safe here. & -0.122 & 0.290 & $\mathbf{0 . 4 5 1}$ \\
\hline You can use the public library and the web. & $\mathbf{0 . 5 9 4}$ & 0.023 & -0.158 \\
\hline People understand each other. & 0.115 & 0.067 & $\mathbf{0 . 7 8 1}$ \\
\hline There are opportunities to do sports. & $\mathbf{0 . 6 9 8}$ & 0.121 & 0.032 \\
\hline Traditions are supported. & 0.211 & $\mathbf{0 . 3 4 4}$ & 0.332 \\
\hline There are good conditions for young people to start their lives. & $\mathbf{0 . 6 9 1}$ & -0.208 & 0.340 \\
\hline Those who want to do business find an opportunity here. & $\mathbf{0 . 6 9 6}$ & -0.193 & 0.246 \\
\hline There is affordable housing here. & $\mathbf{0 . 5 4 5}$ & -0.205 & 0.324 \\
\hline Services are available here. & $\mathbf{0 . 8 1 4}$ & -0.005 & 0.008 \\
\hline It is close to attractive nature. & 0.075 & $\mathbf{0 . 6 9 3}$ & 0.049 \\
\hline There is a good connection with the city. & $\mathbf{0 . 6 3 2}$ & -0.034 & -0.168 \\
\hline There is better water than in the city. & -0.044 & $\mathbf{0 . 6 4 4}$ & 0.167 \\
\hline There is healthy air. & -0.063 & $\mathbf{0 . 7 5 6}$ & 0.201 \\
\hline Tourism is supported. & $\mathbf{0 . 5 7 1}$ & 0.174 & 0.041 \\
\hline Medical care is available here. & $\mathbf{0 . 6 7 7}$ & 0.087 & -0.148 \\
\hline There is a healthy environment. & 0.052 & $\mathbf{0 . 7 6 3}$ & 0.205 \\
\hline There are good relations among neighbours. & 0.028 & 0.250 & $\mathbf{0 . 7 6 5}$ \\
\hline It is possible to build family houses here. & $\mathbf{0 . 4 3 0}$ & -0.126 & 0.224 \\
\hline There is the possibility to buy good for daily use. & $\mathbf{0 . 6 8 5}$ & 0149 & -0.033 \\
\hline There are forests in the neighbourhood & -0.020 & $\mathbf{0 . 6 7 1}$ & -0.120 \\
\hline I can find a job. & $\mathbf{0 . 6 3 8}$ & -0.237 & 0.239 \\
\hline I can realize myself in my free time. & $\mathbf{0 . 4 8 0}$ & 0.189 & 0.169 \\
\hline Source own processing in SPSS SW & & &
\end{tabular}

Source: own processing in SPSS SW

The values of the component scores served as the input variables for the cluster analysis, which was to reveal the typical villages of the Czech countryside from the point of view of their inhabitants. The K-means method was used for clustering. Villages in the sample were divided into five clusters. The number of clusters was estimated by clustering using the Ward method.

By cluster analysis, five groups of municipalities according to the perception of their inhabitants were identified: 1 - a group of municipalities with a high quality natural environment, but insufficient conditions for business, services and possibilities of employment, which may negatively influence the potential development of tourism; 2 - a cluster of municipalities with high quality natural conditions, social capital, leisure opportunities, promotion of traditions and tourism; 3 - a cluster of municipalities where respondents in 10 statements out of a total of 22 expressed predominantly neutral, responses negatively to the issue of tourism support, as well as to statements about entrepreneurial opportunities and opportunities to find employment, but positively evaluated interpersonal relationships; 4 - municipalities with a high quality natural environment, a neutral attitude towards the quality of interpersonal relationships, lack of services and opportunities for entrepreneurship; however, where tourism is supported; 5 - a group of municipalities with a 
high quality environment, limited possibilities for self-realization of the population and neutral support of tourism.

Table 11 Share of particular types of municipalities according their inhabitants' perception with respect to rural typology $(\%)$

\begin{tabular}{|l|l|l|l|l|l|}
\hline \multirow{2}{*}{$\begin{array}{l}\text { municipality type (rural } \\
\text { typology) }\end{array}$} & \multicolumn{6}{|l|}{ municipality type (respondents' perception) } \\
\cline { 2 - 6 } & 1 & 2 & 2 & 4 & 5 \\
\hline $\begin{array}{l}\text { non-profiled } \\
\text { countryside }\end{array}$ & $16.4(15.2)$ & $43.4(24.1)$ & $2.6(6.4)$ & $29.6(27.2)$ & $7.9(8.7)$ \\
\hline $\begin{array}{l}\text { problematic recreational } \\
\text { countryside }\end{array}$ & $52.2(58.8)$ & $13.5(9.1)$ & $10.0(29.5)$ & $9.1(10.2)$ & $15.2(20.3)$ \\
\hline $\begin{array}{l}\text { stable developing } \\
\text { countryside }\end{array}$ & $1.1(1.5)$ & $45.9(36.5)$ & $8.1(28.2)$ & $20.7(27.2)$ & $24.1(37.8)$ \\
\hline $\begin{array}{l}\text { stable non-developing } \\
\text { countryside }\end{array}$ & $20.7(15.2)$ & $44.0(19.4)$ & $2.0(3.8)$ & $27.3(19.9)$ & $6.0(5.2)$ \\
\hline suburban countryside & $11.9(9.3)$ & $22.5(10.6)$ & $15.6(32.1)$ & $20.0(15.5)$ & $30.0(27.9)$ \\
\hline
\end{tabular}

Note: The first value represents the frequency within a given type of municipality. the value in brackets frequency within a given cluster.

Source: own processing in SPSS SW

Tab. 11 shows the distribution of individual types of municipalities identified according to the perception of respondents within the typology of municipalities obtained by the analysis of "hard data". The Chi-square test ( $p$-value $=0.000)$ confirms the statistically significant dependency of the perception of municipalities by their population ("soft" factors) and typology generated by "hard" data analysis. Due to the subjectivity of individual respondents' opinions, it is understandable that different types mingle.

\section{CONCLUSIONS}

This comparison confirms that "hard" and "soft" development factors really affect each other. The development potential of rural municipalities is not only due to their location, infrastructure, size, etc., but human capital and social capital also play a significant role in the quality, activity and viability of the local population. Detailed analysis of the individual clusters and their mutual comparison when seeking profile of rural inhabitants showed that all clusters significantly differ statistically in all dimensions. It confirmed hypotheses 1 and 3 . Subsequent evaluation of respondents' perception of their municipality also confirmed the statistically significant dependency of the perception of municipalities by their population ("soft" factors) and typology generated by "hard" data analysis thus confirming hypotheses 2 and 4. Therefore, rural development strategies need to be designed so that both sets of factors are in line with the aim of synergy. The hard localization factors themselves, without supporting the development of soft factors, do not have the desired effect.

The current countryside is characterized by a high growth in recreational (consumer) functions after 1990 (Marsden, 1998; McAreavey and McDonagh, 2010), when the increased 
demand for the rural leisure environment in the sense of spending free time (instead of consumption of its goods) was triggered. The process by which local resources are valorised and subsequently transformed into products of consumption is referred to as commodification. In the case of the countryside, Woods (2011) talks about different forms of consumption: consumption of countryside, clean air, unique nature, rural culture, traditions, cuisine and products.

The development of tourism has been a very attractive theme in recent decades and most of the municipalities in the Czech Republic are preparing or developing some tourist attractions. However, tourism is not suitable for every rural area (Binek et al., 2007), because it is a sector that requires significant public and private investment for its high-quality development, and the economic impacts are often uncertain and unstable (e.g. seasonal). It turns out that the importance of tourism for development is in some cases overestimated and the benefits and incomes achieved do not reach the visions of the actors or predominantly serve certain groups only (see e.g. Horáková and Fialová, 2012). Tourism can develop in key sectors only in certain areas, it is mostly complementary activity with limited economic benefits.

Each region, each municipality, each development actor must therefore clearly define what type of development he/she is considering, and what kind of development he/she is aiming for. Recently, endogenous approaches based on the initiation of activity within the local community are promoted (Gursoy et al., 2010) - approaches based on local resources and local conditions that support creativity - BOTTOM - UP approaches, approaches that improve the quality of life in the village and set a new standard of living. A typical example is the use of the LEADER program or the CLLD method.

Well-suited, gentle types of tourism can provide jobs in the countryside to positively influence the regeneration and maintenance of rural, natural and cultural heritage. However, the development of rural tourism should be pursued through the development of specific "non-mass" forms associated with rural actors (agritourism, ecotourism, wine tourism, gastronomy focused on local specialties etc.). An indispensable condition for the sustainable development of tourism in rural areas is the consensus among the actors concerned in this development, especially the acceptance by the local community as show many examples in various European countries (e.g. Haven-Tang and Jones, 2012; Panyik et. al., 2011; Hegarty and Przezborska, 2005).

The real recovery of the countryside (through the development of tourism) relies primarily on its inhabitants, on their activity and entrepreneurship, on the capacities and enthusiasm of representatives of municipalities, on the joint efforts of all rural actors - citizens, the nonprofit sector, entrepreneurs, representatives of municipalities and regionalists working within municipalities' areas. 


\section{REFERENCES}

Allen, L., R., Long, P., T., Perdue, R., R., \& Kieselbach, S. (1988). The impact of tourism development on resident's perceptions of community life. Journal of Travel Research, 27(1), 16-21.

Andereck, K., L., Valentine, K., M., Knopf, R., C. \& Vogt, C. A. (2005). Residents' perceptions of community tourism impacts. Annals of Tourism Research, 32(4), 10561076.

Andereck, K. L., Nyaupane, G. P. (2011). Exploring the nature of tourism and quality of life perceptions of community tourism impacts. Annals of Tourism Research, 50(3), 248260.

Ap, J., \& Crompton, J. L. (1988). Developing and testing a tourism impact scale. Journal of Travel Research, 37(2), 120-130.

Ap, J. (1992). Residents' perceptions on tourism impacts. Annals of Tourism Research, 19(4), 665-690.

Bartoš, M. et al. (2011). Amenitní migrace do venkovských oblastí České republiky. Kostelec nad Černými Lesy: Nakladatelství Lesnická práce, s. r.o.

Binek, J., Toušek, V., Galvasová, I., Věžník, A., Kunc, J., Seidenglanz, D., Halásek, D., Rehák, S. (2007). Venkovský prostor a jeho oživení. Brno: Georgetown.

Bramwell, B. (1994). Rural Tourism and Sustainable Rural Tourism. Journal of Sustainable Tourism, 2(1-2), 1-6.

Briedenhann, J., \& Wickens, E. (2004). Tourism routes as a tool for the economic development of rural areas - vibrant hope or impossible dream? Tourism Manangement, 25(1), 71-79.

Butler, R. W., Hall, C. M., \& Jenkins, J. (eds., 1998). Tourism and Recreation in Rural Areas. Chichester: John Wiley.

Cawley, M., \& Gillmor, D. A. (2008). Integrated rural tourism: Concepts and Practice. Annals of Tourism Research. 35(2), 316-337.

Cosma, S., Paun, D., Bota, M., \& Fleseriu, C. (2014). Innovation - a useful tool in the rural tourism in Romania, 148, 507-515.

Costa, C. A., \& Chalip, L. (2005). Adventure Sport Tourism in Rural Revitalisation - An Ethnographic Evaluation. European Sport Management Quarterly, 5(3), 257-279.

Dimitrovski, D. D., Todorovic, A. T., \& Valjarevic, A. D. (2012). Rural Tourism and Regional Development: Case Study of Development of Rural Tourism in the Region of Gruta. Serbia. Procedia Environmental Sciences, 14, 288-297.

Easterlin,. D. S. (2005). Residents and tourism. Journal of Travel Tourism Marketing, 18(4), 49- 64 .

Eligh, J., Welford, R. \& Ytterhus, B. (2002). The production of sustainable tourism: Concepts and examples from Norway. Sustainable Development, 10(4), 223-234.

Frantál, B., \& Kunc, J. (2008). Hodnocení potenciálního vlivu výstavby větrných elektráren na územní rozvoj cestovního ruchu: př́klad rekreační oblasti Slezská Harta. Urbanismus a územní rozvoj, XI(6), 24-29.

Fredline, E., \& Faulkner, B. (2000). Host community reactions: A cluster analysis. Annals of Tourism Research, 27(3), 763-784.

Giddens, A. (1984). The Constitution of Society: Outline of the Theory of Structuration. Cambridge: Polity Press.

Granovetter, M., S. (1973). The Strenght of Weak Ties. In: American Journal of Sociology, 78, 1360-1380.

Gursoy, D., \& Chi, C. G., Dyer, P. (2009). An examination of locals' attitudes. In: Annals of Tourism Research, 29(1), 79-105. 
Gülcan, Y., Kustepeli, Y., \& Akgüngör, S. (2009). Public Policies and Development of the Tourism Industry in the Aegean Region. In: European Planning Studies, 17(10), 15091523.

Hall, D., Mitechell, M., \& Roberts, L. (2003). Tourism and the countryside: Dynamic relationship. - In. Hall, D., Mitchell. M., Roberts. L. (eds): New Directions in Rural Tourism. Aldershot: Ashgate.

Haven-Tang, C., \& Jones, E. (2012). Local leadership for rural tourism development: A case study of Adventa, Monmouthshire, UK. Tourism Management Perspectives, 4, 28-35.

Havlíček, T. (2007). Regionální diferenciace lidského a sociálního kapitálu ve venkovských perifernich oblastech Česka. In: Agrární perspektivy XVI. Evropské trendy v rozvoji zemědělství a venkova. Sborník prací z mezinárodní vědecké konference. ČZU, Praha, 861-871.

Hegarty, C. \& Przezborska, L. (2005). Rural and agri-tourism as a tool for reorganising rural areas in old and new memeber states - a comparison study of Ireland and Poland. International Journal of Tourism Research, 7(2), 63-77.

Horáková, H., \& Fialová, D. (2012). Transformace venkova. Turismus jako forma rozvoje. Plzeň: Vydavatelství a nakladatelství Aleš Čeněk.

Hummelbrunner, R., \& Miglbauer, E. (1994). Tourism promotion and potential in peripheral areas: The Austrian case. Journal of Sustainable Tourism, 2(1-2),

Chalupová, M., Rojík, S., \& Prokop, M. (2017). Image kraje Vysočina jako výzva pro regionální marketing. Studia Turistica, 3, 43-50.

Chromý, P., Semian, M., \& Kučera, Z. (2014). Regionální vědomí a regionální identita v Česku: př́ípadová studie Českého ráje. Geografie, 119(3), 259 - 277.

Ilbery, B. (ed.) (1998). The Geography of Rural Social Change. Harlow: Longman.

Jamal, T. B., \& Getz, D. (1995). Collaboration theory and Community tourism planning. Annals of Tourism Research, 22(1), 186- 04.

Jarábková, J., Majstríková, L', \& Kozolka, T. (2016). Financial supporting tools of rural tourism development in Nitra self-governing region. European Countryside, 2, 123 134.

Kim, K., Uysal, M. \& Sirgy, M. J. (2013). How does tourism in a community impact the quality of life of community residents? Tourism Management, 36, 527-540.

Klufová, R. (2016). Current Delimitation and Typology of the Czech Countryside and its Importance for Rural Development. Eastern European Countryside, 22, 229 -251.

Ko, D. W., \& Stewart, W. P. (2002). A structural equation model of residents' attitudes for tourism development. Tourism Management, 23(5), 521-530.

Lane, B. (1994). What is Rural Tourism? Journal of Sustainable Tourism, 2(1), 7-21.

Lane, B. (2009). Rural Tourism: An overview. In: Jamal. T., Robinson. M. (eds.): The SAGE Handbook of Tourism Studies. 2009, London: Sage Publications, pp. 355-372.

Lankford, S. V., \& Howard, D. R. (1994). Developing a tourism impact attitude scale. Annals of Tourism Research, 21(1), 121-139.

Lee, T. H. (2013). Influence analysis of community resident support for sustainable tourism development. Tourism Management, 34, 37 - 46.

Lindnerová, I., Pachrová, S. (2012). Vztah místního obyvatelstva k rozvoji cestovního ruchu ve zvláště chráněných územích. Studia turistica, 2, 6-10. Retrieved from https://www.vspj.cz/soubory/download/id/1574.

Linting, M. et al. (2007). Psychological Methods, 12(3), 336-358.

Macbeth, J., Carson, D., \& Northcote, J. (2004). Social Capital. Tourism and Regional Development: SPCC as a Basis for Innovation and Sustainability. Current Issues in Tourism, 7(6), 502-522.

Marsden, T. (1998). New rural territories: Regulating the differentiated rural spaces. Journal of Rural Studies, 14(1), 107-117. 
March, R., \& Wilkinson, I. (2009). Conceptual tools for evaluation tourism partnerships. Tourism Management, 30(3), 455 - 462.

Mcareavey, R., \& Mcdonagh, J. (2010). Sustainable Rural Tourism: Lessons for Rural Development. Sociologia Ruralis, 51(2), 175-194.

Meulman, J. J., \& Heiser, W. J. (1993). PASW Categories 18. Chicago: SPSS Inc., pp. 28-39.

Musil, J., \& Müller, J. (2008). Vnitřní periferie České republiky, sociální soudržnost a sociální vyloučení. Praha: CESES. FSV Univerzita Karlova v Praze. [online]. [cit. 5. 12. 2015]. Dostupné na WWW www.ceses.cuni.cz/CESES-20-version1-s06_02.pdf

Navrátil, J., Lesjak, M., Pícha, K., Martinát, S., Navrátilová, J., White Baravalle Gilliam, V.L., ...Rajchard, J. (2014). The importance of vulnerable areas with potential tourism development: A case study of the bohemian forest and south bohemia tourism regions. Acta Geographica Slovenica, 54 (1), 115-130.

Navrátil, J., Pícha, K., Knotek, J., Kučera, T., Navrátilová, J., \& Rajchard, J. (2013). Comparison of attractiveness of tourist sites for ecotourism and mass tourism: The case of waters in mountainous protected areas. Tourismos, $8(1), 35-51$.

Navratil, J., Švec, R., Pícha, K., \& Doležalová, H. (2012). The location of tourist accommodation facilities: A case study of the Sumava Mts. and South Bohemia tourist regions (Czech Republic). Moravian Geographical Reports, 20(3), 50-63.

Nunkoo, R., \& Ramkissoon, H. (2012). Modeling community support for a proposed integrated resort project. Journal of Sustainable Tourism, 18(2), 257-277.

Panyik, E., Costa, C., \& Rátz, T. (2011). Implementing integrated rural tourism: An eventbased approach. Tourism Management, 32(6), 1352-2363.

Pásková, M. (2003). Kapacita území turistického regionu Český ráj pro udržitelný rozvoj cestovního ruchu. COT Business, 6, I-WII.

Patočka, J., \& Heřmanová, E. (2008). Lokální a regionální kultura v České republice. Praha: ASPI.

Pecáková, I. (2014). Problém chybějících dat v dotazníkových šetřeních. Acta Oeconomica Pragensia, 22(6), 66-78.

Perlín, R., Kučerová, S., \& Kučera, Z. (2010).. Typologie venkovského prostoru Česka. Geografie, 115(2), 161-187.

Petr, O. (2012). Venkovský cestovní ruch v kontextu rozvoje českého venkova. Czech Journal of Tourism, 1(2), 135-155.

Pisseli, F. (1999). Capitale sociale: un concetto situazionale e dimanico. In: Stato e Mercato, 57, 395417.

Putnam, R. (1993). Making Democracy Work: civic tradition in modern Italy. Princeton: Princeton University Press.

Putnam, R. (2001). Social Capital. Measurement and Consequences. ISUMA - Canadian Journal of Policy Research. Social Capital, 2(1), 41-51.

Roberts, L., \& Hall, D. (2001). Rural Tourism and Recreation. Principles to Practice. Wallingford. UK - Cambridge. MA: CABI Publishing.

Roberts, L., \& Hall, D. (2004). Consuming the countryside: Marketing for „rural tourism“. Journal of Vacation Marketing, 10(3), 253-263.

Řezanková, H. (2010). Analýza dat z dotazníkových šetření. Praha: Professional Publishing.

Saarinen, J. (2006). Traditions of sustainability in tourism studies. Annals of Tourism Research, 33(4), $1121-1140$.

Sharpley, R., \& Roberts, L. (2004). Rural Tourism - 10 Yerars On. International Journal of Tourism Research, 6(3), 119-124.

Stříbrná, M. (2005). Venkovská turistika a agroturistika. Praha: Profi Press.

Sutherland, L. A. (2012). Return of the gentleman farmer?: Conceptualising gentrification in UK agriculture. Journal of Rural Studies, 28(4), 568- 76.

Šulc, Z., \& Řezanková, H. (2015). Dimensionality Reduction of Categorical Data: Comparison of HCA and CATPCA Approaches. In: Jindřichův Hradec: Applications of Mathematics and 
Klufová, R., Šulista, M.

Statistics in Economics. International Scientific Conference. 2015. [Available at/Dostupné na: http://amse2015.cz/doc/Sulc_Rezankova.pdf]

Wall, G., \& Mathieson, A. (2006). Tourism: changes. impacts. and opportunities. Harlow. New York: Pearson Prentice Hall.

Zelenka, J., \& Pásková, M. (2012). Výkladový slovník cestovního ruchu. Praha: Linde Praha. 